\title{
Correction to: Impact of organic contaminants from dumpsite leachates on natural water sources in the Enugu Metropolis, southeastern Nigeria
}

\section{Ifeoma Linda Onyekwelu • \\ Okechukwu Pius Aghamelu (D)}

Published online: 26 December 2019

(C) Springer Nature Switzerland AG 2019

Correction to: Environ Monit Assess (2019) 191:543.

https://doi.org/10.1007/s10661-019-7719-2

Unfortunately, the name of the first author was incorrectly captured in the published online paper.

The first author publication name should have been Ifeoma Linda Onyekwelu instead of Ifeoma Lindsey Onyekwelu.

The corrected author name is shown above.

Publisher's note Springer Nature remains neutral with regard to jurisdictional claims in published maps and institutional affiliations. 